\title{
The Catholic 1968: Poland, Social Justice, and the Global Cold War
}

\author{
Piotr H. Kosicki
}

In the 1960s, the Catholic Church underwent a revolution in the teaching and practice of its faith. The Second Vatican Council, held from 1962 to 1965, endeavored to "open" the Church to the modern world by embracing-among other practices-freedom of conscience, dialogue with other religions, and the everyday vernacular of the faithful (for example, allowing mass to be conducted in languages other than Latin). An institution defined by its universal designs on humankind pivoted away from a two-thousand-year tradition of claiming a monopoly on salvation. Although other religions-and other Christian denominations-also underwent change in these years, no other church had Catholicism's capacity to assemble bishops and theologians from across the world in one Roman aula with the leader of their faith; the transmission of Vatican II's outcomes was global. For theological as well as geopolitical reasons, the 1960s saw Catholics stake a claim to new forms of agency in world affairs. ${ }^{1}$

Inside and outside the Catholic Church, the 1960s was a decade of fundamental cultural, social, and political transformation the world over. ${ }^{2}$ Gerd-Rainer Horn has argued that the year 1968, in particular, witnessed a "transnational effort not only to imagine but also to construct the contours of community-but a community stripped of hypocrisies, power hierarchies, and the marginalization and suppression of imagination and revolt." 3 Meanwhile, Anne E. Gorsuch and Diane P. Koenker have translated these observations across the Iron Curtain, arguing that there was also a "socialist" sixties, whose transformative cultural power extended well beyond the classically-understood spatial boundaries of the Soviet bloc. ${ }^{4}$ Finally, James Mark, Robert Gildea, and Anette Warring have captured the pan-European reach of 1968, bridging the historiographical divide between Europe's "East"

My sincere thanks to Theodora Dragostinova, Małgorzata Fidelis, and Harriet Murav for soliciting this publication and offering extensive feedback throughout the revision process, and to the two diligent and dedicated anonymous readers for Slavic Review. For their input on earlier drafts of this text, I thank also James Chappel, Nicholas Levy, Hugh McLeod, Norman Naimark, and Molly Pucci. Finally, my thanks to Paul Dembiński and Bernard Margueritte for their testimony.

1. John W. O’Malley, What Happened at Vatican II (Cambridge, Mass., 2008); Giuseppe Alberigo, "Preface: 1965-1995: Thirty Years after Vatican II," in Giuseppe Alberigo and Joseph A. Komonchak, eds., History of Vatican II, Vol. I (Maryknoll, NY, 1995), xii.

2. Gerard J. DeGroot, The Sixties Unplugged: A Kaleidoscope History of a Disorderly Decade (Cambridge, Mass., 2008).

3. Gerd-Rainer Horn, The Spirit of '68: Rebellion in Western Europe and North America, 1956-1976 (New York, 2007), 2. See also, e.g., Arthur Marwick, The Sixties: Cultural Revolution in Britain, France, Italy, and the United States, c. 1958-1974 (New York, 1998); Mark Kurlansky, 1968: The Year That Rocked the World (New York, 2004).

4. Anne E. Gorsuch and Diane P. Koenker, eds., The Socialist Sixties: Crossing Borders in the Second World (Bloomington, 2013). 
and "West." ${ }^{5}$ As much as a discrete chronological interval, "1968" has become a rich semantic signifier, a metonym for upheaval and destruction on the one hand, liberation and creation on the other. ${ }^{6}$

Although this article explores the 1960s as a continuum of global rupture, its narrative anchor is the year 1968, in which a series of transformative events-including the Tet Offensive in Vietnam, successive assassinations in the United States, student protests in Poland and France, the Prague Spring, and the Vatican's denunciation of birth control in Humanae Vitae-fueled the rise of global networks of activists seeking to promote social justice. In this laboratory of globalization, Catholics sought to play a leading role: guided by the utopian goal of a worldwide just society, they pioneered new visions of political economy and sexual politics. Was it more urgent to redistribute wealth from former colonizers to the post-colonial world, or instead to multiply the populations of the formerly colonized? By drawing attention to Catholics' transnational and transregional agency in these kinds of global debates, this article teases out a distinctively Catholic 1968.

Yet this is more than a story of religion's changing role in the international system: examining the Catholic 1968 reveals the entanglements of deStalinization, decolonization, and the global Cold War. ${ }^{7}$ James Mark and Péter Apor have rightly called for historians to explore "the role of the decolonizing world in the imagination of post-Stalinist Eastern Europe."8 Yet the arrow of transnational agency pointed not only from south to east, but in the other direction as well. A newly global Cold War also globalized European forms of knowledge production in political economy and sociology. The history of the Catholic Church offers a uniquely-powerful lens to reveal how old divisions were broken down and once-provincial stories globalized-while, at the same time, others retreated into provincialism.

The Catholic 1968 is therefore a story of intersecting globalities, in which Catholic universalism clashed with Cold War divisions. The result was a series of transfers and encounters unfolding simultaneously along multiple geographical axes: "East-West," "North-South," and "East-South." Following David Engerman's approach to "the Second World's Third World," this article both draws upon and problematizes the vocabulary of "First," "Second," and "Third" Worlds. ${ }^{9}$ While dismissed as an anachronism by many scholars since

5. Robert Gildea, James Mark, and Anette Warring, eds., Europe's 1968: Voices of Revolt (New York, 2013).

6. Karol Edward Sołtan, "The Divided Spirit of the Sixties," in Vladimir Tismaneanu, ed., Promises of 1968: Crisis, Illusion, and Utopia (Budapest, 2011), 131-56.

7. On "entangled history," see Hartmut Kaelble, "Between Comparison and Transfers-and What Now? A French-German Debate," in Heinz-Gerhard Haupt and Jürgen Kocka, eds., Comparative and Transnational History: Central European Approaches and New Perspectives (New York, 2009), 33-38; on the global Cold War, see Odd Arne Westad, The Global Cold War: Third World Interventions and the Making of Our Times (Cambridge, Eng., 2005).

8. James Mark and Péter Apor, "Socialism Goes Global: Decolonization and the Making of a New Culture of Internationalism in Socialist Hungary, 1956-1989," Journal of Modern History 87, no. 4 (2015): 855.

9. David C. Engerman, “The Second World's Third World," Kritika: Explorations of Russian and Eurasian History 12, no. 1 (Winter 2011): 183-211. 
the end of the Cold War, these terms nonetheless convey the mental mappings of Catholics in the 1960s-including Alfred Sauvy, the French Catholic demographer who coined them. ${ }^{10}$ Echoing Sauvy, this article speaks of the First World in reference to western Europe and Anglophone North America, the Second for the Soviet bloc and Soviet Union, and the Third for what would later be called the Global South. ${ }^{11}$

This article represents a first attempt to explore these intersecting globalities, reinscribing the sacred into a historiography dominated by an image of the 1960s as an era of secular cultural revolution. The stakes of writing religion into this narrative are high: as a revolutionary moment of encounter between the religious and the secular, "the sixties may turn out to have been more important than even the Renaissance or Reformation."12 The Catholic story of the 1960s cuts across traditional divides in global political economy. It was a cross-Iron Curtain story, affecting communist and non-communist countries in Europe, as well as developing countries across the world.

This is an exercise in "entangled history," but it has a distinct spatial and sociological anchor: the "Catholic intelligentsia" of communist Poland. ${ }^{13}$ During World War II, and once again in the mid-1950s under de-Stalinization, Poland's Catholic intellectuals-like the anti-Russian insurrectionaries of a century earlier-styled themselves an "intelligentsia."14 Their cause, however, was not the nation, but the global community of their faith. Two crucial teachings handed down by Pope Paul VI in the years following Vatican II-1967's Populorum Progressio, which focused on global resource redistribution, and 1968's Humanae Vitae, which restated the Church's opposition to birth control-stirred the Poles to action. These intellectuals reached across the Iron Curtain into the First World, but they also sought a grassroots role in promoting social justice in Africa, Asia, and Latin America. ${ }^{15}$ Meanwhile, seeking to understand the papal pronouncements, Catholic intellectuals the

10. Alfred Sauvy, “Trois mondes: Une planète,” L’Observateur no. 118 (August 14, 1952).

11. Jonathan Rigg, for example, argues, "the addition of the word 'global' makes it clear that this is not a strict geographical categorization of the world but one based on economic inequalities which happens to have some cartographic coherence. It also emphasizes that both North and South are, together, drawn into global processes rather than existing as separate slices of the world," Jonathan Rigg, An Everyday Geography of the Global South (London, 2007), 3.

12. Callum G. Brown, Religion and the Demographic Revolution: Women and Secularization in Canada, Ireland, UK, and USA since the 1960s (Woodbridge, UK, 2012 ), 29.

13. The classic formulation of the "entangled history" approach is Sebastian Conrad, Shalini Randeria, and Beate Sutterlüty, Jenseits des Eurozentrismus: Postkoloniale Perspektiven in den Geschichts- und Kulturwissenschaften (Frankfurt, 2002).

14. Jerzy Jedlicki, A Suburb of Europe: Nineteenth-Century Polish Approaches to Western Civilization (Budapest, 1999), 173-292; Piotr H. Kosicki, Personalizm po polsku: Francuskie korzenie polskiej inteligencji katolickiej, trans. Jerzy Giebułtowski (Warsaw, 2016), 34-35.

15. On Iron Curtain crossings, see Michael David-Fox, "The Iron Curtain as SemiPermeable Membrane: The Origins and Demise of the Stalinist Superiority Complex," in Patryk Babiracki and Kenyon Zimmer, eds., Cold War Crossings: International Travel and Exchange across the Soviet Bloc, 1940s-1960s (College Station, TX, 2014), 14-39; Simo Mikkonen and Pia Koivunen, eds., Beyond the Divide: Entangled Histories of Cold War Europe (New York, 2015). 
world over-from Paris to Accra-looked to communist Poland, the world's laboratory for activism at the intersection of Catholicism and socialism. ${ }^{16}$

In July 1968, French Catholic activists from the "New Life" organization (La Vie Nouvelle), wary of fraternizing with co-religionists facing political repression in Poland, aborted a cross-Iron Curtain initiative on Catholic international development that had been intended to respond to Populorum Progressio. One month later, the Swiss-based Catholic organization Pax Romana-piloted by a uniquely situated Polish secretary-general who came to Fribourg not from among western Europe's postwar exile population, but direct from communist Poland-abandoned its own plans for responding to the 1967 encyclical with a program for global social justice. Instead, Pax Romana fractured along geopolitical lines in response to two benchmarks of the summer of 1968: the Vatican announcement of Humanae Vitae (July 25) and the invasion of Czechoslovakia by Warsaw Pact forces (August 20-21).

What follows is a story of disappointment, rather than triumph. Polish Catholic intellectuals were empowered as transnational actors by deStalinization, only to learn in the course of the Global Sixties that, because they hailed from behind the Iron Curtain, there was no place for them in the Global West. Theirs is a story of Catholics attempting to globalize but getting caught in geopolitical scissors even as they formed linkages across continents and transoceanic spaces. The global Cold War constituted the horizon line for the transnational agency of the Polish Catholic intelligentsia: as western Europeans and North Americans withdrew from a global Catholic program of social justice, Poles doubled down on cooperation with the Global South, leveraging "international development" against western opposition to Catholic restrictions on birth control. A geopolitical conflict thereby took on distinctively social, economic, and cultural dimensions as well. In the end, the global Cold War reified the very divisions that had launched it.

\section{Catholic Activism across the Iron Curtain}

Prior to Vatican II, Rome consistently described Catholics living in the Soviet bloc as trapped in a "church of silence." ${ }^{17}$ Nonetheless, one must not confuse the political constraints and repression behind the Iron Curtain with a lack of agency on the part of its inhabitants. As scholars like Małgorzata Fidelis and Padraic Kenney have shown through the study of gender and labor, the Soviet bloc was not the "totalitarian" monad depicted in the work of Zbigniew K. Brzeziński. ${ }^{18}$ Roman Catholics, too-however beleaguered in the day-to-

16. On Polish Catholics' long history of entanglement with the social question, see Piotr H. Kosicki, Catholics on the Barricades: Poland, France, and "Revolution," 1891-1956 (New Haven, CT, 2018).

17. Pope Pius XII originally coined the term. See Jonathan Luxmoore and Jolanta Babiuch, The Vatican and the Red Flag: The Struggle for the Soul of Eastern Europe (London, 1999), 103; Piotr H. Kosicki, "Introduction," in Piotr H. Kosicki, ed., Vatican II behind the Iron Curtain (Washington, DC, 2016), 4-5.

18. Zbigniew K. Brzeziński, The Soviet Bloc: Unity and Conflict, 2nd ed. (Cambridge, Mass., 1967 [1960]); for an important corrective, see Małgorzata Fidelis, Women, Communism, and Industrialization in Postwar Poland (New York, 2010), 15. 
day practice of their faith-preserved their connection to the global institution to which they belonged, drawing on its universalism to defy their countries' autocratic rulers. In the end, Catholics behind the Iron Curtain remained "resourceful shapers of their own destiny."19

Celebrated as Polish-born Pope John Paul II has been for his role in ending the Cold War, rare is the acknowledgment that eastern Europeans in the aggregate-not just Poles, but also Czechs, Croats, and Hungarians-were active agents of the Catholic Church's global transformation in the twentieth century. ${ }^{20}$ To the extent that Stalinism had been prohibitive of east European Catholics' active engagement in the life of the Church outside their region, this was no longer the case in the 1960s. Poland played a uniquely active role, for it had the freest Catholic Church of any communist country, as well as a growing Catholic intelligentsia conversant in global debates, thanks to opportunities unavailable to Catholics elsewhere in the bloc, particularly regular travel abroad that bred transnational networks of interlocutors and collaborators on multiple continents. ${ }^{21}$

Following the cooptation of episcopal hierarchies at the turn of the 1940s and 1950s in Czechoslovakia, Hungary, and Yugoslavia, Polish Catholic intellectuals took on the uniquely weighty responsibility of speaking on behalf of more than just their own national community of faith. Their stated goal was to test the conditions of possibility for Catholics and Marxists to work together not only for Poland's advancement, but on behalf of global social justice as well. Yet in the wake of the Holocaust and postwar border shifts, the population of Poland was-confessionally and ethnonationally-nearly homogeneous. Under Stalinism, ethnonationalism dominated Catholic discourse in Poland. ${ }^{22}$

Beginning in 1956, however, de-Stalinization meant that Catholic intellectuals could follow a different path. Following his reinstatement as general secretary of the Polish United Workers' Party, Władysław Gomułka personally authorized the creation of a new movement of the Catholic intelligentsia, called Znak (Sign). ${ }^{23}$ Its clubs and journals-despite being subject to censorship and, occasionally, censure-afforded the intelligentsia the autonomy to denationalize and deconfessionalize the norms that Catholics were to follow

19. Padraic Kenney, Rebuilding Poland: Workers and Communists, 1945-1950 (Ithaca, NY, 1997), 336.

20. See the essays in Kosicki (ed), Vatican II behind the Iron Curtain.

21. See Piotr H. Kosicki, "Caritas across the Iron Curtain? Polish-German Reconciliation and the Bishops' Letter of 1965," East European Politics and Societies 23, no. 2 (May 2009): 213-43.

22. Michael Fleming, Communism, Nationalism, and Ethnicity in Poland, 1944-50 (London, 2010); Kosicki, Catholics on the Barricades, 152-88, 257-302; Mikołaj Stanisław Kunicki, Between the Brown and the Red: Nationalism, Catholicism, and Communism in Twentieth-Century Poland-The Politics of Bolesław Piasecki (Athens, OH, 2012), 77-110.

23. On Gomułka's return to power, see Paweł Machcewicz, Rebellious Satellite: Poland, 1956, trans. Maya Latynski (Washington, DC, 2009). On the genesis of Znak, see Andrzej Friszke, Oaza na Kopernika: Klub Inteligencji Katolickiej, 1956-1989 (Warsaw, 1997); Christina Manetti, "Sign of the Times: The Znak Circle and Catholic Intellectual Engagement in Communist Poland, 1945-1976” (PhD diss., University of Washington, 1998), $140-262$. 
in secular life. Granted the permission to travel to France, Ghana, and the Philippines (among other countries), the men and women of Znak styled themselves representatives of all Catholics behind the Iron Curtain-as Europeans and Catholics "who came in from the cold" each time they crossed the Iron Curtain. ${ }^{24}$ The Catholic MP and publisher Tadeusz Mazowiecki spoke for his entire movement when, in 1963, he remarked to an international audience in Brussels that the Polish Catholic experience set the precedent for "the laity in any socialist country." 25

Since before World War II, the more intrepid among Poland's Catholic intellectuals had been reading French philosophy and social theory. In the early years of communist Poland, they corresponded and met with leading French Catholic philosophers who visited Poland, most notably the editors of the monthly journal Esprit (Spirit), Emmanuel Mounier and Jean-Marie Domenach. ${ }^{26}$ The collapse in 1958 of a French Fourth Republic overburdened by the bloody loss of overseas empire in Indochina and Algeria called into question, however, France's traditional status as an authority for Polish Catholics. By the end of the 1950s, de-Stalinization and decolonization had invalidated old assumptions guiding Franco-Polish Catholic contacts: it was no longer Poles looking to learn from French "masters," but the reverse. Znak activists traveling to western Europe reported having been "met at every step with particular good will, favor, and interest" as a consequence of "the global fascination with our country in the wake of October [1956]."27

The French fascination with communist Poland seemed to offer genuine prospects for Catholic partnerships piercing the Iron Curtain. Inspired by Mounier's personalist philosophy, former scouts who had fought in the French Resistance came together after World War II, looking to forge new paths to a just society. Under the leadership of scoutmaster André Cruiziat, La Vie Nouvelle (The New Life) blossomed into a nationwide network of social radicals opposed to the capitalism of the French Fourth and Fifth Republics. ${ }^{28}$ Just as Mounier had traveled to pre-Stalinist Poland in 1946 in the hope of learning from a newly communist country, so his disciples in the New Life looked in the 1960 s to post-Stalinist Poland, hoping to find the key to a socially-just political economy. ${ }^{29}$ To gain first-hand information about Polish successes and failures, Cruiziat organized a series of fact-finding missions (voyages d'études) intended to carry out the movement's goals of developing "new solidarities across the world" and of shaping "the world of today and of tomorrow." The

24. Ludwik Dembiński, "The General Secretary 'Who Came in From the Cold', in Michela Trisconi, ed., Mémoires engagées / Memorias comprometidas / Memories of committed persons (Fribourg, Switz., 1997), 89-98, esp. at 94.

25. Tadeusz Mazowiecki, "Mission et liberté des laïcs en pays socialiste," in Georges Hourdin, Mission et liberté des laïcs dans le monde (Paris, 1964), 33.

26. John Hellman, Emmanuel Mounier and the New Catholic Left, 1930-1950 (Toronto, 1981); Kosicki, Catholics on the Barricades, 152-88, 257-302.

27. Jerzy Turowicz, "Światowy kongres prasy katolickiej,” Tygodnik Powszechny, September 8, 1957.

28. Emmanuel Mounier, Révolution personnaliste et communautaire (Paris, 1935); Jean Lestavel, “La Vie Nouvelle”: Histoire d'un mouvement inclassable (Paris, 1994).

29. Emmanuel Mounier, “L’ordre règne-t-il à Varsovie?” Esprit, no. 6 (June 1946): 970-1003; Kosicki, Catholics on the Barricades, 135-44. 
French and the Poles thus brought their respective movements together: Znak pledged to host the French Catholics in Poland, and La Vie Nouvelle would return the favor. ${ }^{30}$

When the French were in Poland, the Poles covered their expenses; when the Poles came to France, the French did the same. Given the logistical challenges of Cold War currency dealings, it seemed a fair trade. La Vie Nouvelle sent members on fact-finding missions to Poland in 1960, 1961, 1963, and 1967. In the intervening years, Cruiziat also organized trips to Czechoslovakia, Hungary (twice), the USSR, and Yugoslavia (twice), as well as Algeria, Morocco, and Tunisia. The post-colonial and post-Stalinist spaces alike became such frequent destinations that Cruiziat set up a special "service for international exchanges" within his movement to handle the logistics. By the mid-1960s, it seemed that the New Life might actually provide a roadmap for global Catholic dialogue on how to build a just society.

\section{A Catholic Program of International Development?}

The year in which this dialogue almost came together was 1968. The previous year, Pope Paul VI had handed down the encyclical Populorum Progressio, which seemed to fall exactly in line with the French Catholics' project of looking beyond the First World to nurture "solidarities" with diverse populations across the globe. ${ }^{31}$ Cruiziat, like the Roman pontiff, believed that "it is most important for people to understand and appreciate that the social question ties all men together, in every part of the world.” To that end, Paul VI had just empowered a new Vatican commission called Iustitia et Pax (Justice and Peace) "to awaken in the People of God full awareness of their mission today. In this way they can further the progress of poorer nations and international social justice, as well as help less developed nations to contribute to their own development." 32 The very slogans of La Vie Nouvelle's fact-finding missions seemed borne out by the ground-breaking papal pronouncement, which defined three prerequisites to the worldwide resolution of the social question: mutual solidarity, social justice, and universal charity.

In the 1940s, both camps in the emerging Cold War had introduced ideologies of "international development" to justify their respective hegemonic aspirations. As Frederick Cooper notes: "Postwar imperialism was the imperialism of knowledge." 33 Roman Catholics, however, began in the war's immediate aftermath to chart their own course of international development, navigating

30. Archives de la Province Dominicaine de France, Paris (hereafter APDF), André Cruiziat Papers, Box 104 (Pour découvrir les Nouvelles Solidarités Mondiales: Nos Voyages d'Études [1963]); APDF, André Cruiziat Papers, Box 104 (Constantin [Konstanty] Łubieński to André Cruiziat, November 8, 1963).

31. Paul VI, Populorum Progressio, March 26, 1967, at http://w2.vatican.va/content/ paul-vi/en/encyclicals/documents/hf_p-vi_enc_26031967_populorum.html (last accessed June 28, 2018).

32. Paul VI, “Catholicam Christi Ecclesiam,” Acta Apostolicae Sedis no. 59 (1967): 27.

33. Frederick Cooper, "Modernizing Bureaucrats, Backward Africans, and the Development Concept," in Frederick Cooper and Randall Packard, eds., International Development and the Social Sciences: Essays on the History and Politics of Knowledge (Berkeley, 1997), 64. 
between First and Second Worlds. As Giuliana Chamedes observes: "the Catholicizing of economic development was part and parcel of the Vatican's attempt to recast its relationship with western Europe and decolonize itself." 34

This effort extended far beyond the walls of the Vatican, however. Populorum Progressio represented the culmination of a long process of Catholic intellectual ferment, which Vatican II had finally legitimated and brought into the Catholic mainstream. The 1967 papal teaching encouraged Catholics to develop a radically different idea of social justice from the charity and corporatism that the Holy See had taught since the late nineteenth century. ${ }^{35}$ Namely, Paul VI made it clear that the faithful were no longer to conceive of a just society strictly in terms of Europe's industrial proletariat, but instead as a global problem involving diverse peoples, races, regions, and continents. The priority was for Catholics-especially in Europe and in North Americato turn away from capitalism. ${ }^{36}$ The pontiff insisted: "Genuine progress does not consist in wealth sought for personal comfort or for its own sake; rather it consists in an economic order designed for the welfare of the human person, where the daily bread that each man receives reflects the glow of brotherly love and the helping hand of God." 37

Arturo Escobar has rightly noted that "development" has, since World War II, often served as code for an Orientalizing power play of sorts: "a discursive formation, giving rise to an efficient apparatus that systematically relates forms of knowledge and techniques of power." ${ }^{38}$ Still, the Catholic turn to international development in the 1960s departed substantially from secular developmentalism. Its foundations were theological, rather than econometric. This was no call to emulate "superior" western knowledge, but rather an incorporation of Latin America, Africa, and Asia into the Catholic revolution in progress since Vatican II. Rather than a beleaguered post-colonial space, the Third World represented a site of hope-a "diaspora church" in the words of Jesuit theologian Karl Rahner, an influential advisor at Vatican II. ${ }^{39}$ This is why Pope Paul VI, too, thought of himself in his extra-European travels as a "pilgrim," not a "missionary." 40

Catholic international development did not abandon the Church's eternal mission of saving souls, but it repackaged that mission as an enterprise of solidarity and pluralism. Populorum Progressio therefore built on existing foundations in "revolutionary" Catholic philosophy and theology, as well as

34. Giuliana Chamedes, "The Catholic Origins of Economic Development after World War II," French Politics, Culture \& Society 33, no. 2 (June 2015): 59.

35. Paul Misner, Social Catholicism in Europe: From the Onset of Industrialization to the First World War (New York, 1991), 3.

36. James Chappel, Catholic Modern: The Challenge of Totalitarianism and the Remaking of the Church (Cambridge, Mass., 2018), esp. 59-107, 227-60.

37. Paul VI, Populorum Progressio, March 26, 1967.

38. Arturo Escobar, Encountering Development: The Making and Unmaking of the Third World (Princeton, 1995), 10; see also Wolfgang Sachs, ed., The Development Dictionary: A Guide to Knowledge as Power (London, 1992).

39. Karl Rahner, Theological Investigations, vol. V, trans. Karl-H. Kruger (London, 1966), 115; Piotr H. Kosicki, "Vatican II and Poland," in Kosicki, ed., Vatican II behind the Iron Curtain, 173-74.

40. Jacek Woźniakowski, Laik w Rzymie i w Bombaju (Kraków, 1965), 229. 
the pontiff's own pioneering travels as a pilgrim (to India, to Israel), offering a model for his successors (most notably, John Paul II) to emulate. ${ }^{41}$ The encyclical's language made clear that Catholics could no longer conceive of the dignity of the human person in isolation from discourses of international development.

La Vie Nouvelle responded enthusiastically to the 1967 teaching. Its members, in fact, aspired to lead the Church's new projects of international development. They looked across the Iron Curtain for answers to the dilemma of how to redistribute resources more justly to the Third World, examining the successes and failures of capital redistribution within the Soviet bloc. For the French activists, this meant once again turning to Poland. Between January and March 1968, La Vie Nouvelle's international service developed a detailed fact-finding agenda, conceived as the launching pad for an east-west forum on international development.

When invitations went out across France on March 15, 1968, the New Life leadership anticipated an intensive three-week study trip, with the main event a four-day conference co-sponsored with Znak. ${ }^{42}$ Plans included keynote speeches by two Catholic publishers: Poland's Tadeusz Mazowiecki and Belgium's Jean Delfosse. ${ }^{43}$ In the spirit of Vatican II, the stated purpose was to bridge "Christendoms of East and West." Unlike at the Council, however, that phrase referred here not to denominational divisions within Christianity (Roman Catholic versus Eastern Orthodox), but instead to the Iron Curtain, conceived as an east-west divide that Catholics from both sides needed to work together to dissolve. ${ }^{44}$ The implication was that, after Populorum Progressio, the Catholic vision of a just society demanded an end to the Cold War.

This self-conscious emphasis on dissolving the Iron Curtain was to be the bedrock of a global dialogue intended to involve First, Second, and Third Worlds all at once. André Cruiziat's international office made clear in its design for the proposed four-day conference that the best elements needed to be taken from both capitalist and communist political economy in order to yield the sort of practical innovation that might actually produce a just outcome for the post-colonial world. This is not to say that the French papered over the authoritarian nature of the Polish communist regime; in fact, La Vie Nouvelle openly criticized the "monopolization of decision-making power" by the Polish United Workers' Party. ${ }^{45}$

For the French, postwar Poland represented a test case in what to do-and, even more so, what not to do-in response to "the dilemmas of modern man."

41. James Ramon Felak, "Pope John Paul II, the Saints, and Communist Poland," Catholic Historical Review 100, no. 3 (Summer 2014): 555-74.

42. "Schéma du Colloque Franco-Polonais Juillet 1968: Société-ParticipationDéveloppement” (March 1968), Archives Nationales du Monde du Travail (ANMT, Roubaix), 60AS179.

43. On Delfosse, see, e.g., Jean-Louis Jadoulle, Chrétiens modernes? L'engagement des intellectuels catholiques “progressistes” belges de 1945 à 1958 (Louvain-la-Neuve, 2003).

44. See, e.g., Vitaly Borovoy, "The Meaning of Catholicity," The Ecumenical Review 16, no. 1 (1963): 26-32; ANMT, 60AS179 (Micheline Benarous to Lucien Driot), December 2, 1965.

45. ANMT, 60AS179 (Schéma du Colloque Franco-Polonais Juillet 1968), 2.

46. As Vie Nouvelle's international service director Lucien Driot explained in a letter to his Znak counterpart, the French encounter with Polish colleagues "would not be devoted solely to intellectual debate, but would indeed be complemented and illustrated 
A coherent response to Populorum Progressio demanded alternatives to the modern "tendency to consume without end objects of mass production." ${ }^{\text {"7 }}$ The object, rather, was to pinpoint a "phenomenon of socialization" such that "an equilibrium might be reached between the person and society, between power and participation." 48 Communists had achieved tangible successes in the realm of social welfare and class mobility, and the French Catholics looked to their Polish partners to help them cull from the Polish example the best of what the communists had done, without the repressive politics. Before sitting down at the conference table, the French Catholics were to tour mines, state farms, and urban planning offices-meeting technocrats, rather than ideologues - to unlock the technical details behind the infrastructure of communist Poland.$^{49}$ France and Poland, two Catholic countries with longstanding cultural ties, seemed the perfect partners to launch this dialogue.

\section{The Global Cold War vs. International Development}

For all of the promise of this plan, however, contingent circumstances caught La Vie Nouvelle by surprise. By mid-April, the group's international office was seriously weighing the trip's cancellation, or at least a change in destination. The key clue in the New Life archives lies in an article cut out from the March 2, 1968 issue of Le Monde and included with the planning documents for the 1968 fact-finding mission. Its author was Bernard Margueritte, Le Monde's Polish correspondent and one of the best-informed journalists covering the Soviet bloc. Fresh from conversations with the university students Adam Michnik and Henryk Szlajfer, he reported their plans to launch sit-in protests at universities all over Warsaw. ${ }^{50}$

The trigger for the protests was the banning, under Soviet pressure, of stage performances of one of Poland's canonical national dramas-Forefathers' Eve, by the Polish bard Adam Mickiewicz. ${ }^{51}$ At the same time, there were much deeper processes at work: a power struggle within the communist leadership, an anti-Semitic purging of the Party and of public life more generally, and uncertainty over the future of the Soviet bloc in the face of reforms being introduced in Czechoslovakia-the so-called "socialism with a human face"-by Alexander Dubček. ${ }^{52}$

by the study of Poland's specific case and its principal dimensions of activity," ANMT, 60AS179 (Lucien Driot to Wacław Auleytner), January 25, 1968.

47. ANMT, 60AS179 (Schéma du Colloque Franco-Polonais Juillet 1968), 2.

48. ANMT, 60AS179 (Schéma du Colloque Franco-Polonais Juillet 1968), 1, 3.

49. ANMT, 60AS179 (Voyage Pologne 13-31 juillet 1968: Liste des rencontres officielles), September 2, 1968.

50. Bernard Margueritte, "Les écrivains de Varsovie revendiquent le droit de participer à l'élaboration de la politique culturelle,” Le Monde, March 2, 1968. esp. ix.

51. Roman Koropeckyj, Adam Mickiewicz: The Life of a Romantic (Ithaca, NY, 2008),

52. On the Polish student protests-Jerzy Eisler, "March 1968 in Poland," in Carole Fink, Philipp Gassert, and Detlef Junker, eds., 1968: The World Transformed (Cambridge, Eng., 1998), 237-52. On the anti-Semitic purges-Dariusz Stola, "Anti-Zionism as a Multipurpose Policy Instrument: The Anti-Zionist Campaign in Poland, 1967-1968," in Jeffrey Herf, ed., Anti-Semitism and Anti-Zionism in Historical Perspective: Convergence and 
The March 1968 protests took on a life of their own, with images circulating internationally of Polish militia units turning truncheons and water cannons on students in streets across Poland, together with news of both protest leaders and sympathetic professors losing their university positions. Znak's five MPs also took a stand, with the movement's leader, playwright Jerzy Zawieyski, delivering from the parliamentary rostrum a fiery condemnation of the regime's brutal repression of the students. ${ }^{53}$ For his troubles, Zawieyski lost his seat in parliament, suffered a stroke, and one year later fell to his death under mysterious circumstances from a window in the sanatorium where he was recuperating.

Reading Margueritte's accounts of these events apparently drove the Vie Nouvelle leadership into a panic. Marcel Borrel, who was to lead the trip, wrote to the head of La Vie Nouvelle's international service: "I fear greatly that the position taken by Znak on the Polish students, followed by the direct attacks on that group in the parliament, will prevent us from carrying out a voyage of an official nature on the proposed subject." 54 Feeling that it was imperative to change plans, Borrel proposed either replacing Poland with Czechoslovakiawhich, ironically, he deemed "certainly more stable"-or adopting a one-time solution of re-profiling the journey from fact-finding mission to mere tourism. Nowhere in the group's internal correspondence does one find expressions of sympathy for the students, dismay at their repression, or admiration for the position taken in the protesters' defense by Znak.

In the end, La Vie Nouvelle chose to send a smaller group-thirteen, rather than twenty-five-to Poland as tourists. Their subsequent report shows that they retained much of the original program, meeting with agrarian experts, touring a coal mine, and quizzing the urban planners of "socialist realism" in between walking tours of Polish cities and kayak trips down Polish rivers. ${ }^{55}$ What dropped off the agenda, however, was its heart and soul: the FrancoPolish conference on international development. Nor was there any engagement with Poland's most pressing issue of the day: the fallout from March. Although La Vie Nouvelle's public report on the journey to Poland did not ignore the issue entirely, it buried the events on pages 51-53 out of over 100, in a small heading entitled "Some problems of the youth and of students." The broad strokes used to paint a picture of the protests-occupations, committees, communication by telephone-make it clear that instead of doing the kind of first-hand fact-finding for which La Vie Nouvelle was known, the

Divergence (London, 2007), 159-85. On “socialism with a human face," see Zdeněk Mlynař and Mikhail Gorbachev, Conversations with Gorbachev: On Perestroika, the Prague Spring, and the Crossroads of Socialism, trans. George Shriver (New York, 2002).

53. On March 11, Zawieyski declared in the name of the five Znak MPs, "On March 8 and 9, protesting youth were beaten with incredible brutality, often in a manner endangering their lives. There were many reports of cruelty, including toward women.... The solution is not to suppress the demonstrations, but rather to avoid losing the ability to communicate with society," Jerzy Zawieyski, "Interpelacja Koła Posłów 'Znak' do premiera z 11 marca 1968 r. w związku z wystąpieniami studenckimi i brutalną interwencją milicji i ORMO,” in Andrzej Friszke, Koło posłów 'Znak' w Sejmie PRL 1957-1976 (Warsaw, 2002), 488-89.

54. ANMT, 60AS179 (Marcel Borrel to Lucien Driot), April 20, 1968.

55. ANMT, 60AS141 (Rapport-Pologne 1968, April 1969).

56. ANMT, 60AS141 (Rapport-Pologne 1968), 51. 
French Catholics were superimposing onto Poland their own observations from the French student uprising of May 1968. ${ }^{57}$

La Vie Nouvelle's abortive 1968 voyage d'études to Poland is a case study in missed opportunities. Faced with the prospect of standing against the USSR and its satellite governments, the French activists instead allowed their program of global Catholic dialogue to fall by the wayside. Poland's transnational "Catholic 1968" began with the promise of La Vie Nouvelle and Znak linking arms across the Iron Curtain to advance the Church's new agenda of international development. Yet Cold War contingency trumped transnational agency-at a moment that was perhaps most auspicious for French and Polish Catholics to take a stand of solidarity together, in the aftermath of Vatican II, just as they were brainstorming how best to serve justice in the Global South.

As such, the promise of inter-world efforts to advance the interests of postcolonial peoples was lost in translation across the Iron Curtain..$^{58}$ Rather than understand Poland's March '68 as a moment of spontaneous social upheaval in response to political repression, the leadership of La Vie Nouvelle saw it first and foremost as a roadblock to the fulfillment of their own goals. Unwilling to undertake international "dialogue" in the spirit of Paul VI by lending public support to their Polish counterparts-if not before or during their July 1968 journey to Poland, then at least afterwards, in their public report-they reduced their expectations to tourism and avoided controversy at all costs.

In so doing, the French Catholics went against the very logic of their factfinding missions. Even though Paris experienced its own student uprising a mere two months after the first student protests in Warsaw, the French failed to look for structural similarities between these two cases of student protest against transgressions by a political regime. Given their lack of solidarity with counterparts across the Iron Curtain, despite the fact that the Vie Nouvelle voyage did indeed take place in July 1968, its legacy was that of a missed opportunity for Europeans east and west to work together to promote international development. In this first case study of the Catholic 1968, a Catholic project of social justice with global aspirations ran aground on the Cold War.

\section{The "Second" World Meets the "Third"}

While La Vie Nouvelle was hesitating over the future of its fact-finding missions, other Catholic international organizations undertook serious efforts to build grassroots ties between the post-Stalinist and post-colonial worlds. Having seen bishops from all over the globe converge on Rome for four successive autumns, international organizations of the laity began to seek a similar level of national, linguistic, and racial diversity. ${ }^{59}$ When Vatican II

57. On the mutual misunderstandings of the '68ers from Warsaw and Paris, see Paul Berman, A Tale of Two Utopias: The Political Journey of the Generation of 1968 (New York, 1996); Adam Michnik, Bernard Kouchner, and Jolanta Kurska, Rozmowy w Awinionie (Warsaw, 2014).

58. Sołtan, "The Divided Spirit of the Sixties," 143-44.

59. Melissa J. Wilde, "How Culture Mattered at Vatican II: Collegiality Trumps Authority in the Council's Social Movement Organizations," American Sociological Review 69, no. 4 (August 2004): 577. 
concluded in 1965, one particular international organization stepped in to recruit lay activists from across all three "worlds." This was Pax Romana, based in Fribourg, Switzerland. This organization would become a bellwether for spaces of overlap and contestation between the global Cold War and the global Catholic agenda of social justice.

Founded in 1921 as an international network of Catholic students, refashioned in 1947 to include also a second, parallel network of post-graduates, Pax Romana for decades hewed close to the Holy See.$^{60}$ In the 1920 s and 30s, eastern Europeans had been among the organization's founding members, and Poles, Hungarians, Czechs, and Slovaks had both attended and hosted Pax Romana congresses before $1939 .{ }^{61}$ Beginning with the outbreak of the Second World War, however, east European participation in Pax Romana ceased for almost two decades, until after the onset of de-Stalinization.

Beginning in 1956, Pax Romana developed plans to rebuild its membership behind the Iron Curtain. The cornerstone was to be Poland's Catholic intelligentsia, led by Znak. As Thom Kerstiens, head of Pax Romana's student network, explained clearly in a 1958 interview with the Znak journal Tygodnik Powszechny (Universal Weekly): "Catholics the world over are paying close attention to the condition of Catholics in Poland." 62 That included-Kerstiens continued-Catholics in sub-Saharan Africa whom the global Cold War had put on the front lines of the fight against communist encroachment. ${ }^{63}$

Paradoxically, it was the American effort in the global Cold War that first opened the door to the Third World for Catholic intellectuals from communist Poland. Relying on mediation by Polish political émigrés, the CIA-backed Free Europe Committee (FEC) bankrolled the international travels of Catholics from Poland for whom de-Stalinization had begun to part the Iron Curtain. Seen as potential Catholic political cadres for a future postcommunist Poland, hand-picked activists from Znak had the opportunity to journey not only to western Europe, but even to the Third World. ${ }^{64}$ Free Europe Committee money also encouraged the Pax Romana leadership to recruit from among the most

60. Philippe Chenaux, Une Europe Vaticane? Entre le Plan Marshall et les Traités de Rome (Brussels, 1990), 67-74; Ramon Sugranyes de Franch, Die internationalen katholischen Organisationen (Aschaffenburg, 1972).

61. There are extensive files documenting east European academic participation in annual Pax Romana congresses-Warsaw even hosted one in 1927. See Archiwum Uniwersyteckie Katolickiego Uniwersytetu Lubelskiego Jana Pawła II (the Archives of the John Paul II Catholic University of Lublin), Pax Romana File.

62. "O międzynarodowej współpracy katolików: rozmowa z Thomem Kerstiensemsekretarzem generalnym Pax Romana MIIC,” Tygodnik Powszechny, October 12, 1958.

63. See also Thom Kerstiens, The New Elite in Asia and Africa: A Comparative Study of Indonesia and Ghana (New York, 1966), 202-10, 233-36.

64. Polish activists belonging to the exiled Christian Labor Party (Stronnictwo Pracy) received funds from the Free Europe Committee to facilitate contacts between young Polish Catholic activists and west European counterparts, with an eye toward "training new cadres": Archives of the Polish Institute of Arts and Sciences of America (New York), Karol Popiel Papers, Box 9.10 (Stanisław Gebhardt, "Sprawozdanie o sytuacji na emigracji przedstawione na Radzie SP na Wychodźstwie,” November 18-19, 1956); Piotr H. Kosicki, "Christian Democracy's Global Cold War," in Piotr H. Kosicki and Sławomir Łukasiewicz, eds., Christian Democracy across the Iron Curtain: Europe Redefined (London, 2018), 221-55. 
talented Catholic intellectuals in the Soviet bloc. As Pax Romana's sponsor at Free Europe wrote to a colleague in 1965: "the work of Pax Romana has increased enormously in Eastern European Catholic student circles. . .mostly by funds given by FEC for this particular activity, i.e. the building up of a network of Catholic students in Eastern Europe who deal with one another and with Western-based Catholic student groups." 65

One of the first FEC beneficiaries was a twenty-nine-year-old Polish legal scholar named Ludwik Dembiński, a co-founder of Znak who taught at the Catholic University of Lublin. Scion of an old aristocratic family, Dembiński, like most of his generation in Znak, was a serious believer in CatholicMarxist partnership. Dembiński shared the philosophy of his friend Tadeusz Mazowiecki: "we strive constantly for a dialogue between Catholics and nonbelievers. We see this as a method of coexistence that presupposes that both sides constantly and reciprocally act upon one another, instead of turning their backs to each other and shutting themselves off from one another." 66

Rather than enter the national political arena like Mazowiecki, Dembiński made his life's passion the fate of peoples and lands affected by the liquidation of European overseas empires in Africa and Asia. ${ }^{67}$ Given his fluency in English, French, and German, Dembiński seemed a natural fit. When Pax Romana came to Znak in early 1957 to propose that the Poles designate one of their own for a fact-finding mission to sub-Saharan Africa, Dembiński volunteered..$^{68}$

Over the course of the next decade, he made four separate trips to the decolonizing world-in 1957, 1959, 1960, and 1966-despite being closely monitored by the Polish communist security apparatus. On his first trip, which took him to Africa for over two months, Dembiński visited Dakar, Abidjan, Lagos, Ibadan, Accra, Leopoldville (Kinshasa), Bukavu, Nairobi, and Kampala. In Accra, the Polish activist attended a Pax Romana-sponsored seminar, one of only a handful of Europeans present. Dembiński described the seminar as a laboratory of social justice for a post-colonial world:

The choice of the venue of the Accra seminar was not accidental: it [1957] was the first year of Ghana's independence and as such symbolized aspirations of all Africans. For me-as certainly for most participants-it was a most fascinating affair. The seminar gathered Catholic students from all over Africa, including-which was most extraordinary-a mixed group of black and white students from South Africa. The seminar was followed by a work camp in the bush, somewhere near Kumasi, where we were supposed to improve a

65. Hoover Institution Archives, Stanford, CA, RFE/RL Inc. Corporate Records, Box 252.14 (Eugene L. Metz to George C. Minden, December 3, 1965).

66. Mazowiecki, "Mission et liberté des laïcs en pays socialiste," 43.

67. See Ludwik Dembiński, "Une expérience de formation et de recherche en relations internationales en Afrique,” Genève-Afrique/Geneva-Africa 18, no. 1 (1980); Ludwik Dembiński, "Territory and the Development of International Law," Annuaire Suisse de Droit International no. 21 (1975).

68. Dembiński, "The General Secretary 'Who Came In from the Cold'," 91-92; the Polish security apparatus's account is at Archiwum Instytutu Pamięci Narodowej, Warsaw (hereafter AIPN), BU 01208/2603/J (Doniesienie agenturalne z dn. 9.XI.59 r. [Codename "Stefan"]). 
local road. The white South African students admitted that sharing physical work with their black colleagues was for them a unique and most rewarding experience, absolutely impossible in their own country. ${ }^{69}$

At each stop, Dembiński had met with local Catholic elites, embracing Third World voices while becoming the first person from behind the Iron Curtain to have such extensive contact with the emerging Catholic vanguard of sub-Saharan Africa. ${ }^{70}$ When he returned to Poland in the spring of 1958, he published a series of reports in Tygodnik Powszechny, intended to bring the experience of Catholics living through decolonization to an audience of Catholics living through de-Stalinization. The young legal scholar reported, "a great revolution is in progress. Not only the hierarchy, but also the regular clergy have come to appreciate the role that university-educated Catholics can play in shaping the future face of Africa.... Whether this opportunity is seized or lost is up to Catholics the world over. The Church in Africa is still too weak, the obstacles confronting it too great, for it to overcome them on its own." 71 Ludwik Dembiński's travels did not make headlines, but he blazed a trail for the Catholic pursuit of social justice in a decolonizing world assimultaneously-a Polish, east European, and global actor.

Dembiński was unequaled among his Znak colleagues in terms of his subject-area training and linguistic skills, but his was no idiosyncratic vision. Rather, his skill set and his connections with Pax Romana had made him the Polish Catholic intelligentsia's person of choice by the mid-1960s to translate the Polish experience of Catholic socialism to a global vision of social justice. The litmus test for this process of translation was the capacity of the result to meet the challenges of the post-colonial world. On his fourth trip abroad-to Belgium, in 1966-he received an invitation to become the first east European secretary-general in the history of Pax Romana. There followed a frenzied correspondence within the Polish communist establishment, involving the Politburo, security apparatus, and Office of Confessional Affairs (which answered directly to the prime minister). ${ }^{72}$ Initially dubious about allowing an independent Catholic intellectual to represent communist Poland abroad, the secret police and the regime's religion experts soon reached a consensus. In November 1966, Aleksander Skarżyński, the head of the Office of Confessional Affairs, together with Col. Stanisław Morawski, who oversaw all Catholic-related operations within the security apparatus, argued on Dembiński's behalf to the Politburo. This was effectively a letter of recommendation for Dembiński and for Polish Catholic leadership in an era of international development. The officer directly responsible for monitoring Dembiński explained why:

69. Dembiński, “The General Secretary 'Who Came In from the Cold', 91.

70. On these emerging elites, see Paul Gifford, Christianity, Development, and Modernity in Africa (New York, 2016); Jeffrey Haynes, Religion, Politics, and International Relations: Selected Essays (London, 2011), 57-76. 1958.

71. Ludwik Dembiński, “Wielka szansa Kościoła,” Tygodnik Powszechny, August 20, 95-107.

72. Barbara Fijałkowska, Partia wobec religii i Kościoła w PRL, vol. I (Olsztyn, 1999), 
I believe that the assumption by Ludwik Dembinski of the position of secretary-general of Pax Romana can have positive consequences for the country, particularly with respect to confessional policy. Pax Romana is today the most distinguished international organization of the Catholic intelligentsia bringing together analogous organizations from about seventy countries. . . . It shows reformist tendencies in its attitude toward socialist countries and in its attitude toward the so-called "Third World."73

In the end, the Polish communist regime signed off on Dembiński's candidacy, making him the only non-émigré Pole to hold a leadership position in international Catholic structures after World War II until Karol Cardinal Wojtyła's election as Pope John Paul II in 1978. At the same time, there was an important caveat: the communist ideologues and technocrats understood Dembiński's leadership of Pax Romana to be an "experiment." The expectation was that the Pole's attachment to the new Catholic agenda of international development would make him an effective opponent of American foreign policy-in other words, that he would be an ally of Soviet bloc interests in the global Cold War. In this, the Polish officials were correct. ${ }^{74}$

\section{Sex, Decolonization, and the Prague Spring}

In 1968, it became clear that Ludwik Dembiński was fated to preside over Pax Romana's transformation from a principally continental network focused on promoting Europe's proletariat to a global Catholic network concerned above all with the Third World. In this transformation, Pax Romana closely followed the lead of Pope Paul VI, when he used Populorum Progressio to redefine the Catholic vision of a just society. As Dembinski later explained, "in this new situation, the question had to be asked what should be the specific role and functions to be played in the future by the traditional international Catholic organizations, and particularly by Pax Romana."75

The publication of Populorum Progressio in 1967 had been a watershed moment in the Church's history, yet only sixteen months later Paul VI seemed to be derailing that teaching with a second encyclical that ostensibly contradicted the first. Though limited in scope to marriage and reproduction,

73. AIPN BU 01208/2603/J (Tomasz Wawrzyniewicz, Notatka dot. dr Ludwika Dembińskiego i propozycji objęcia przez niego stanowiska sekretarza generalnego "Pax Romana," October 6, 1966, 3). The final recommendation to the Politburo, written jointly by Wawrzyniewicz's chief and the head of the Office of Confessional Affairs, is at AIPN BU 01208/2603/J (Stanisław Morawski and Aleksander Skarżyński, Notatka w sprawie propozycji objęcia przez Ludwika Dembińskiego stanowiska sekretarza generalnego "Pax Romana," November 1966).

74. Morawski and Skarżyński wrote, "The assumption by L. Dembiński of the position of secretary-general of Pax Romana nonetheless retains the qualities of an experiment, as thus far few national-level Catholic activists have joined the ranks of the leaders of international Catholic organizations. It cannot be ruled out that this experiment might have negative consequences, specifically with respect to strengthening the position of the Znak milieu, both among Catholic organizations abroad and-what follows-with respect to tendencies toward aggressive social and political activism at home.” See Morawski and Skarżyński, “Notatka,” 3.

75. Dembiński, “The General Secretary 'Who Came In from the Cold’," 96. 
the July 1968 Humanae Vitae became the linchpin of what I identify as the "Catholic 1968." Calls for the redistribution of resources from the First to the Third World clashed with a growing focus in the post-colonial world on natality and demographic growth, guided by the assumption that more inhabitants would mean a larger labor force, which in turn would accelerate capital transfers from wealthier states. ${ }^{76}$ This was also the Vatican's view. Paradoxically, the sexual revolution gripping North America and western Europe in the 1960s placed Catholics at loggerheads with many of their co-religionists in the Second and Third Worlds alike, who vehemently supported Humanae Vitae. ${ }^{77}$

The 1968 papal statement formalized the Church's ban on all forms of contraception besides "natural cycles immanent in the reproductive system."78 Even as he declared contraception to be anathema, however, Paul VI acknowledged the "rapid increase in population which has made many fear that world population is going to grow faster than available resources, with the consequence that many families and developing countries would be faced with greater hardships." Paul VI recognized the "difficulties confronting the public authorities in this matter, especially in the developing countries," referencing the "justifiable anxieties" that Catholics might feel when attempting to square the two encyclicals. ${ }^{79}$

To resolve this dilemma, the Vatican presented Humanae Vitae as a necessary corrective to Populorum Progressio. In a decade of Euro-American sexual revolution, the pope worried that Vatican II's embrace of the modern world might encourage relaxation of Catholic sexual ethics. ${ }^{80}$ The pontiff thus opened the 1968 encyclical by acknowledging discussions-widespread among Catholics in the three years since the Council's conclusion-"whether, because people are more conscious today of their responsibilities, the time has not come when the transmission of life should be regulated by their intelligence and will rather than through the specific rhythms of their own bodies." 81 Here, however, Paul VI drew a line in the sand: "Neither the Church nor her doctrine is inconsistent when she considers it lawful for married people to take advantage of the infertile period but condemns as always unlawful the use of means which directly prevent conception, even when the reasons given for the later practice may appear to be upright and serious." 82

From the Vatican's perspective, the sanctity of human life was central to the pursuit of social justice; Humanae Vitae was, therefore, not an afterthought to international development, but instead a precondition to its proper

76. See Michael Carder, “A Family Quarrel? ‘Developmentalism’ or Family Planning,” Concerned Demography 4, no. 2 (Winter 1974): 3-12.

77. Brown, Religion and the Demographic Revolution, 127-71; Wannes Dupont, "Catholics and Sexual Change in Flanders," in Gert Hekma and Alain Giami, eds., Sexual Revolutions (New York, 2014), 81-98.

78. Paul VI, Humanae Vitae, July 25, 1968, at http://www.vatican.va/holy_father/paul_ vi/encyclicals/documents/hf_p-vi_enc_25071968_humanae-vitae_en.html (last accessed July 3, 2018).

79. Paul VI, Humanae Vitae.

80. Janet E. Smith, "Humanae Vitae”: A Generation Later (Washington, DC, 1991); Hugh McLeod, The Religious Crisis of the 1960s (Oxford, 2007), 192-93.

81. Paul VI, Humanae Vitae.

82. Ibid. 
and just implementation. As such, Paul VI counted on Catholic intellectuals to help implement his teachings, and he saw a special role for Pax Romana in pointing the way to harmonizing Populorum Progressio with Humanae Vitae. Matters came to a head at Pax Romana's annual congress. Held on August 21-26 at St. Joseph's College in Philadelphia, the 1968 meeting attracted over 300 participants from forty-six countries. Intended to focus on Populorum Progressio's implications for the Third World, the congress carried the theme "Four Faces of Poverty" (economic, social, intellectual, and moral). At its convocation, Pax Romana president Joaquín Ruiz-Giménez read aloud a personal message from the pope declaring that the organization's members "are most highly qualified to conceive, consider, judge, and propose the most fitting and effective means of solving this world problem"-namely, of long-standing theft of resources by colonizers from the colonized. ${ }^{83}$

Even though Paul VI had instructed them to focus on Populorum Progressio, members of Pax Romana instead fixated on the encyclical published only three weeks before the Philadelphia meeting: Humanae Vitae. As a result, the 1968 congress became a referendum on Humanae Vitae, in which all of the tensions between the two encyclicals became apparent. As he played the role of intermediary, Dembiński's status as the only Catholic representative from the Soviet bloc made his presence absolutely pivotal. On the one hand, he believed in Catholic-Marxist dialogue and cooperation. On the other, the Pole rejected what he considered to be the naïveté of his west European and North American colleagues in the Pax Romana secretariat, complaining, for example, about the "political, social, and religious radicalism" manifested in disputes over the "Chinese cultural revolution, the 1967 Arab/Israeli war, apartheid, the racial problems in the US, decolonization, revolutions in Latin America, neo-Marxist theories of international relations, the writings of Marcuse, the marriage of priests, the encyclical Humanae Vitae, not to mention May 68 in Paris." ${ }^{44}$ In some of these controversies, Dembiński sided with secular "radicals," while elsewhere his position appeared more conservative. The explanation for these apparent contradictions is simple: like most members of Znak, Dembiński was a Catholic socialist. In other words, he combined conservatism in matters of doctrine (Humanae Vitae, opposition to the marriage of priests) with radicalism in the field of political economy, which translated into simultaneous commitments to anti-capitalism and anti-colonialism. ${ }^{85}$

The tensions between political and doctrinal radicalism came to a head in August 1968, with Dembiński caught in the middle. The conference's keynote speaker was one of the world's most recognizable Catholic activists

83. Four Faces of Poverty: Economic, Social, Intellectual, Moral: Major Addresses, Preparatory Documents, Conclusions of Commissions, and Final Statements Presented to and Worked on by the $20^{\text {th }}$ Plenary Assembly of the International Catholic Movement for Intellectual and Cultural Affairs (Pax Romana), held at St. Joseph's College, Philadelphia, 21-26 August 1968 (Fribourg, Switz., 1969), mp2.

84. Dembiński, "The General Secretary 'Who Came In from the Cold', 94.

85. See Kosicki, Catholics on the Barricades, 152-88. On the Catholic vanguard's efforts to "decolonize itself," see, e.g., Chamedes, "The Catholic Origins of International Development after World War II," 59. 
for social justice: César Chávez. Rather than lower the discussion's temperature, he raised it to a boiling point. At the age of forty-one, Chávez had already become a household name in the United States following his establishment of the National Farm Workers' Association in 1962 and his leadership of a California grape pickers' strike and boycott that lasted five years, beginning in $1965 .{ }^{86}$ At the 1968 Pax Romana congress, Chávez argued that Catholics-both laity and clergy-had a responsibility to advocate for and act on behalf of workers. He focused on migrant laborers in American agriculture, but his vision was a global one, addressed especially to delegates from across the Third World. Like Paul VI in Populorum Progressio, Chávez insisted that social justice required both class and "world" solidarity. ${ }^{87}$ It was Chávez who challenged the Philadelphia delegates to consider that Humanae Vitae, rather than an attack on or a distraction from international development, must be seen as an essential component of any Catholic vision of social justice. According to Chávez, North American and west European insistence on birth control was simply "another form of capitalist exploitation." 88

In this respect, the Philadelphia meeting manifested the discontents of both decolonization and the global Cold War. In their desire to spread birth control globally by pushing back against Humanae Vitae-Chávez was arguing-Catholics from the First World were trying to compensate for the loss of western Europe's colonies. The idea was to handicap the Third World demographically in its presumptive competition with the First World. As it happened, Chávez read perfectly the mood of Pax Romana's members from Africa, Asia, and Latin America. Ludwik Dembiński put it bluntly: "all the Third World delegations were strongly in favor of Humanae Vitae because they considered birth control and family planning as a weapon of American imperialism directed at them.,"89

Throughout the congress, Dembiński found himself referring back regularly to Chávez's interpretation of Humanae Vitae. In so doing, he brought the Soviet bloc in line with the legendary American activist's vision for the developing world. When he defended Humanae Vitae, Dembiński was doing more than discouraging First World secularism. He also followed Chávez's lead in geopolitics. On the very first day of the congress, Warsaw Pact tanks rolled into Czechoslovakia, suppressing the Prague Spring. ${ }^{90}$ Defending Soviet bloc

86. Miriam Pawel, The Union of Their Dreams: Power, Hope, and Struggle in Cesar Chavez's Farm Worker Movement (New York, 2009), 182-96.

87. See Chávez's insistence that the Catholic Church support its Mexican-American constituents inter alia with "servanthood," rather than "paternalism," in a celebrated speech delivered a mere six months before his Pax Romana keynote. César E. Chávez, "The Mexican-American and the Church," March 8, 1968, at http://www.americanrhetoric.com/speeches/cesarchavezspeechmexicanamerican\&church.htm (last accessed July 3, 2018).

88. Quoted in Philip Daniel, “Pax Romana in the U.S.A.,” The Tablet, September 14, 1968, 19. On this period in Chávez's career, see Frank Bardacke, Trampling Out the Vintage: Cesar Chavez and the Two Souls of the United Farm Workers (New York, 2011), 308-40.

89. Dembiński, “The General Secretary 'Who Came In from the Cold'," 95.

90. Miklós Kun, Prague Spring, Prague Fall: Blank Spots of 1968, trans. Hajnalka Csatorday (Budapest, 1999). 
leaders from American and west European criticism, Dembiński and Chávez both contended that the invasion represented a bona fide defense of socialism.

Seeking to lend coherence to these different positions, the Pole returned time and again to Humanae Vitae. This encyclical, after all, brought Pax Romana delegates from North America and western Europe together against Paul VI; this, in turn, provoked a strong response from the remaining participants. The First World, then, unwittingly united the Second and Third Worlds in defense of Rome. The disagreement was so bitter-both in public and behind closed doors-that Philadelphia's archbishop, the Polish-American John Cardinal Krol, had to intervene personally. ${ }^{91}$ The Pax Romana secretarygeneral from behind the Iron Curtain opposed birth control in Poland, too, but had never written or campaigned on the issue. Nonetheless, the Catholic 1968 brought him onto the world stage as a broker of international debates on sexual politics.

When an American delegate introduced a resolution condemning the Warsaw Pact for its armed suppression of the Prague Spring, Dembiński ensured that delegates representing the Third World got the floor. As the Polish secret police later reported with satisfaction, representatives of developing nations fought back against the American initiative by "immediately bringing up Vietnam, Israel, and Biafra." 92 In other words, the collective line of the Third World in 1968 was that no one had the moral authority to pronounce judgment on the Warsaw Pact invasion of Czechoslovakia, unless they also condemned all the theaters of violence in the global Cold War. The resolution ultimately passed, but by then it was scarcely recognizable: its final text specified no country in particular, merely denouncing violence as a general practice in the conduct of international affairs.

For Dembiński, what was at stake was not Czechoslovak sovereignty but the proper role Catholics should play when the global Cold War threatened to derail the Church's new agenda for international development. Dembiński's priority, in other words, was global justice, rather than national sovereignty (even from Moscow). In December 1966, following his confirmation as Pax Romana's secretary-general for the International Catholic Movement for Intellectual and Cultural Affairs, Dembiński gave an interview on Polish Radio. There he declared that the "struggle against the political program of Marxist regimes is not the task of the Church; not only does it not facilitate, but indeed it hinders the task of the Church's elemental religious and moral mission." 93

In Dembiński's eyes, the legacy of Vatican II hung in the balance by 1968. To maximize its role in assuring cooperation across the "three worlds" on behalf of international development, the Catholic Church needed to stay neutral in a geopolitically divided world. Dembiński was, in fact, consistent

91. See Mark S. Massa, The American Catholic Revolution: How the Sixties Changed the Church Forever (New York, 2010), 63-68.

92. AIPN BU 001136/467/J (Notatka ze spotkania z “Danielem” w dniu 28.IX.br., September 30, 1968, 1).

93. AIPN BU 01208/2603/J (Stenogram wywiadu udzielonego przez Ludwika Dembińskiego, działacza “Znak,” redaktorowi P.R. Góranowskiemu w dn. 20.XII.1966r. o godz. 20.20 w ramach cyklicznej audycji dot. problemów współczesności, 6). 
with the position of the Holy See in arguing that the ecclesiastical reforms of Vatican II did not necessarily imply political anti-communism. ${ }^{94}$ It is this attitude on his part-seeking to leverage geopolitical tensions to achieve tangible progress in the realm of political economy-that explains both his seemingly contradictory political choices and his ultimate inability to control a conversation within Pax Romana that he himself had encouraged. His strategy embodied influential Vatican II theologian Karl Rahner's idea of the "diaspora church"-in other words, an approach to political economy and developmentalism rooted in theologically framed discourses of solidarity and pluralism, rather than a coherent set of secular political commitments.

The delegates to the Philadelphia meeting had confronted one controversial issue after another, and the outcome was tension, rather than cooperation, across the divides separating the First, Second, and Third Worlds. Brushing aside Populorum Progressio's call for "world solidarity," North American and west European delegates seemed to manifest simultaneous antagonism toward "East" and "South"-the former for suppressing the Prague Spring, the latter for a perceived retrograde sexual politics. These antagonisms made it essentially impossible to achieve the kind of dialogue for which Paul VI had called in Populorum Progressio. They contributed, however, to the formation of a growing "East-South" network of Catholic activism on behalf of international development. In the vanguard of this activism was Dembiński, whose commitment to the post-colonial world in fact led him so far as to relocate in 1973 together with his family to Cameroon, where he would spend the better part of a decade, combining academic teaching with grassroots Catholic organization-building. His would be one of the enduring faces of the Catholic 1968.

The Soviet bloc-and, in particular, communist Poland-was at the heart of the Catholic 1968. This phenomenon was born of the tensions between geopolitical revolution (de-Stalinization in the Soviet Union and the Soviet bloc, decolonization in the Third World, a global Cold War) and Catholics' new approaches to pastorship and mission in the wake of the Second Vatican Council. In tandem with the Church's turn to modernity, globalization, and dialogue came controversy at the crossroads of social policy and geopolitics. Paul VI's 1967 attempt in Populorum Progressio to lay the groundwork for a comprehensive Catholic approach to international development-directed simultaneously toward representatives of the First, Second, and Third Worlds-laid bare the practical challenges of negotiating across geopolitical and economic divides. This was the most elemental roadblock to bringing capitalist, communist, and developing worlds into conversation.

In the end, a global program for social justice eluded Catholics. In 1968, the Cold War reared its head in the Tet Offensive and the suppression of the Prague Spring, and the resultant geopolitical divisions multiplied the roadblocks to global solidarity, even among the world's Catholics. Responses to Humanae Vitae inhibited a global consensus on how to enforce Populorum

94. See Hansjakob Stehle, Eastern Politics of the Vatican 1917-1979, trans. Sandra Smith (Athens, OH, 1980), 314-74; Roland Cerny-Werner, Vatikanische Ostpolitik und die DDR (Göttingen, 2011). 
Progressio, with the result that the Global South and the Global East found themselves bound by shared antagonism toward the Global West. Hugh McLeod is right to describe Humanae Vitae as having had "disastrous effects, both short-term and long-term." ${ }^{95}$ While-at least, initially-Poles, as well as Ghanaians, Filipinos, and Hungarians endorsed the encyclical, in the United States and the United Kingdom it became "the single greatest impediment to young women's faith." 96

Yet Paul VI's 1968 teaching was just the most extreme case of damage "done by those at the top or near the top" of the Catholic world to the legacy of Vatican II. ${ }^{97}$ La Vie Nouvelle's sudden retreat in the summer of 1968 from an east-west framework for implementing Populorum Progressio shows that, even as east European Catholics gained prominence as global actors, the politics of the bloc continually circumscribed its Catholics' ability to forge partnerships with the First World. Both the Polish communist response to March ' 68 and the bloc-wide intervention to suppress the Prague Spring divided the activist vanguard of Catholic social justice, setting up cross-Iron Curtain antagonisms in spite of shared confessional and intellectual commitments. Transposing these east European concerns to the international arena, the Cold War hampered a turn to social justice that came from within the Church. After de-Stalinization, Poles were in a position to be trailblazers, but they remained hamstrung by the concomitant globalization of the Cold War across the Global South.

It is in these tensions that one finds also the roots of a diverse array of seemingly contradictory developments in global Catholicism: Latin American liberation theology, communist Poland's eventual pivot to Catholic tradeunionism as embodied by Solidarność (Solidarity), and the growing prominence that Catholic activists from behind the Iron Curtain came to occupy globally in the 1970s and 80s, culminating in the election of Pope John Paul II in 1978. ${ }^{98}$ Ludwik Dembiński, as a secretary-general in Pax Romana from 1967 to 1971, attempted to broker understanding between First and Third Worlds, yet when divisions emerged, he typically sided with developing peoples. The contingent circumstances that catapulted him from communist Poland to the world stage in the 1960s destined him to devote his attention to reconciling the legacies of de-Stalinization, decolonization, and Vatican II.

Clearly, 1968 was a year of paradoxes for the Catholic Church. Lay activists had only just begun the process of moving beyond thinking of their Church in ethnonational or "bloc" terms toward a global community. ${ }^{99}$ Like the French activists of La Vie Nouvelle, who backed away from a cross-Iron Curtain initiative on international development following communist repressions against protesting Polish students, western Europeans assembling in Philadelphia responded to delegates from the developing world with fear,

95. McLeod, The Religious Crisis of the 1960s, 13.

96. Brown, Religion and the Demographic Revolution, 171.

97. McLeod, The Religious Crisis of the 1960s, 13.

98. Paul E. Sigmund, Liberation Theology at the Crossroads: Democracy or Revolution? (New York, 1992), 14-39; Józef Tischner, The Spirit of Solidarity, trans. Marek B. Zaleski and Benjamin Fiore (San Francisco, 1984); Kosicki, Catholics on the Barricades, 303-14.

99. Ian Linden, Global Catholicism: Diversity and Change since Vatican II (New York, 2009); Kosicki, "Vatican II and Poland,” 174-79. 
rather than substantive dialogue. Dembiński's Polish case officers reported: "Delegates from the African and Asian countries demanded immediate aid for starving nations, a just redistribution of Europe's material goods. The tone of their speeches, their self-confidence and ignorance, terrified the European delegates. The vision of a Europe deluged by starving Asians came into stark relief." 100

In the end, it was only a Catholic from behind the Iron Curtain, Dembiński, who could mediate between the three "worlds" on a matter as controversial as Humanae Vitae. The apparent lesson was that if global Catholic cooperation on international development proceeded on terms dictated by the Second and Third Worlds, Roman Catholicism in North America and western Europe would fade to the margins. ${ }^{101}$ This, in effect, is precisely what happened.

After Karol Cardinal Wojtyła was elected pope in 1978, the link between the Second and Third Worlds became a staple of the Catholic imaginary, even as that same pontiff deepened theological rifts with and within the Global South. ${ }^{102}$ John Paul II's early and swift moves against Latin American liberation theology proceeded almost in parallel with the development of Poland's Solidarity trade-union movement. To the pontiff from behind the Iron Curtain, the Latin American option, however well-intentioned, deformed the social question. Meanwhile, as his 1981 encyclical Laborem Exercens made clear, John Paul II saw in Solidarność the proof that Catholics in communist Poland had produced the definitive model for solidarity "on the continental and world level." ${ }^{03}$ Paradoxically, the Soviet bloc became the prism through which the Catholic Church refracted its vision of international development for the Third World-and of social justice for all humankind.

100. AIPN BU 001136/467/J (Notatka ze spotkania z “Danielem” w dniu 28.IX.br., September 30, 1968, 2).

101. Gerd-Rainer Horn, The Spirit of Vatican II: Western European Progressive Catholicism in the Long Sixties (Oxford, 2015), 253-62.

102. See, e.g., Christian Smith, The Emergence of Liberation Theology: Radical Religion and Social Movement Theory (Chicago, 1991), 222-33; Sigmund, Liberation Theology at the Crossroads, 154-75.

103. John Paul II, Laborem Exercens, September 14, 1981, at w2.vatican.va/content/ john-paul-ii/en/encyclicals/documents/hf_jp-ii_enc_14091981_laborem-exercens.html (last accessed July 3, 2018). 